では多重絞りにおいて MTFの低下が見られた。また照 射野外の散乱線の減少については中間絞りの有効性を確 認した。

\section{7. 胸部側面撮影に於ける試作固定具}

栃木獨協医科大学病院

○幕田節男・小黑 清・宇賀神誠

牧野芳文・青木俊夫

〔目的〕胸部撮影は, 単純撮影において件数も多く重 要な検查である，また，胸部撮影の装置も改良されてお り，その進歩はめざましい. 当院にも新しい装置が設置 されているが，件数が多く状態の悪い被検者が来院した 場合には術者が介助することがある，そのような時，患 者の動き，術者の被曝などが問題となってくる，そこで われわれは，患者固定用補助具を試作したので報告する。

〔結果〕 1 . 術者が介助する必要が少なくなり, 術者 の被曝軽減につながる，2．状態の悪い被検者に対して， 動きやフォト受光部をはずれることなく撮影でき有効で ある。 3 ，固定部分は，X 線吸収の少ない材質を使用し ているため X 線写真上に障害陰影とならない。

\section{TLD 校正用標準照射台の試作}

東京医科大学霞ケ浦病院放射線科

○佐藤 斉・田畑仁志・阿部剛士

中島 馨・棣沢 敦・梅田和夫

〔目的〕TLDは高感度で計測の操作が簡単で複数場 所での同時測定や長時間積算測定が可能なため，環境放 射線量や個人被曝線量测定等, 放射線管理線量評価手段 として広く使用されているが，各素子間で放射線レスホ ンスや経時的に感度が変化し, 特性差が測定精度を左右 している，今回素子特性差を補正するために多数素子を 同時，同一条件で均一に標準照射できる台を試作した。

〔方法扔よび結果〕 shadow-shield法，スペクトル法 により散乱線発生の少ないシステムで, 線源と素子を自 転させることにより測定値のバラツキを減らし，精度高 く多数素子の標準照射が可能であった。

\section{9. 簡易肝脈管モテルの作製}

財団法人朝日生命成人病研究所放射線科

○大坪員悟 $\cdot$ 大森秀俊 $\cdot$ 後藤俊英

荒井久勝・斎藤正夫

腹部超音波検查を施行するに当って，検査施行者は， 同定の指標となる脈管の走行を立体的に把握しなければ ならない.しかし, 解剖学書と超音波像を見較べながら イメージしていくには，時間と慣れが必要である。

そこで私共は，最も同定の指標となる胆肝の脈管モデ ルを試作しまた，同時にX 線 film を利用してプローブ
模型を試作した。

このモデルにより超音波像との比較が容易になった為, 肝脈管の立体的イメージが向上し，その結果肝病変の位 置関係を把握しやすくすることができるようになりまし た.

\section{座長集約}

当セクションは，診断用補助具に関するもので，その 内容は診断から，超音波までと幅広いものであった。

演題15は, 試作フィルタの研究で, paper fillter が, $\mathrm{Al}$ フィルタと同等の特性を持ち, 安価で作製が容易にで き，他の部位への応用も可能とのことであった。

質問 $76 \% ， 60 \%$ ウログラフィンのどちらの濃度で フィルターを作製したか.

答 $60 \%$ のほが，エッジ部分の障害陰影が少ないた めに，それを使用した。

演題16は，照射野決定に際し，多重絞りのほかに中間 絞りを設け，面質について検討したものであるが，演者 も指摘しているように，小さい照射野での検討のために 有意差がみられないが，さらに実使用時での検討を望み たい.

演題17は，胸部側面用固定具の開発で，身近かなとこ ろの問題でありながら，撮影業務の大きなウェートを占 める胸部撮影の, 正確さと, 能率化を図るということに 大きく貢献する研究であった。今後の発展を期待したい。

質問 固定具使用により，作業時間はどのように変化 したのか.

答 若干かかるが，現在操作性がよくなるよう考慮中 である。

演題18は，TLD 測定精度向上のため，標準照射台試作 の研究であり，素子，線源を自転させることにより，良 好な結果が得られたとのことである.

演題19は，超音波検查時に肝脈管モデルを作製し，検 㚗および，医師説明に用いるとの内容であったが，作製 手順の説明が若干複雑であり，発表に一工夫欲しいとこ ろである。

最近の放射線機器の開発，進歩に比べて，まだまだ撮 影業務のほうは，経験や，勘にたよる面が多いと思われ るが，そのために生じるポジショニングミスや，撮影時 間の延長，しいては患者利益のためにも，補助具使用に より撮影の能率化をはかることは大切なことと思われる。 今後も，このような地道な研究がもっとなされること を望む。

V CT

座長 松村義光（独協医科大学病院） 